\title{
Correction to: Herbert Tabor (1918-1920): obituary
}

\author{
Peter McPhie ${ }^{1}$
}

Published online: 29 May 2021

(C) International Union for Pure and Applied Biophysics (IUPAB) and Springer-Verlag GmbH Germany, part of Springer Nature 2021

\section{Erratum to: Biophysical Reviews (2020) 12:1285-1286} https://doi.org/10.1007/s12551-020-00774-6

Biophysical Reviews would like to correct an error made in an obituary for Dr. Herbert Tabor published in Volume 12 Issue 6 (McPhie 2020). The correct dates for Dr. Herbert Tabor's life in the title and abstract should have read,

(1918-2020)

Correct title is:

Herbert Tabor (1918-2020): obituary

The journal unreservedly apologizes to the author for not picking up this error during the production and proofing stage.

\section{Reference}

McPhie P (2020) Herbert Tabor (1918-1920): obituary. Biophys Rev 12: 1285-1286. https://doi.org/10.1007/s12551-020-00774-6

Publisher's note Springer Nature remains neutral with regard to jurisdictional claims in published maps and institutional affiliations.

The online version of the original article can be found at https://doi.org/ 10.1007/s12551-020-00774-6

Peter McPhie

1 Silver Spring, USA 